\title{
RUANG KOMUNITAS IBU DAN PASAR DI KRENDANG
}

\author{
Thao Phing ${ }^{1 /} /$ Suwardhana Winata ${ }^{2)}$ \\ 1) Program Studi S1 Arsitektur, Fakultas Teknik, Universitas Tarumanagara, thenthaophing97@gmail.com \\ 2) Program Studi S1 Arsitektur, Fakultas Teknik, Universitas Tarumanagara, danarsitek@gmail.com \\ Masuk: 09-01-2020, revisi: 27-01-2020, diterima untuk diterbitkan: 09-05-2020 (doi: 10.24912/stupa.v2i1.6755)
}

\begin{abstract}
Abstrak
Kota memiliki rekam jejak peradaban manusia dari waktu ke waktu dengan berbagai fenomena yang terjadi di dalamnya. Seiring berjalanya waktu, Third Place di kota Jakarta masih terbatas. Kegiatan yang ditawarkan didalamnya cenderung tidak interaktif. Kebanyakan Third Place di Jakarta mencoba menampilkan sisi ruang terbuka dan penghijauan saja namun tidak berbicara mengenai kegiatan atau wadah bagi masyarakat itu sendiri. Dalam perjalanannya menuju era yang lebih modern, perlu adanya sebuah perubahan terhadap konsep Third Place dimana konsep ini tidak hanya sebagai ruang terbuka saja atau mall melainkan harus dapat mewadahi kegiatan yang dibutuhkan oleh masyarakat disekitarnya. Fasilitas bagi kaum ibu yakni memasak dan bagi anak - anak yakni bermain dan berkreativitas harus menjadi perhatian utama Third Place pada kawasan Krendang. Pada era modern ini masyarakat mulai cenderung menjadi kaum yang individualistis dan terkesan tidak ingin bersosialisasi. Motherhood Community and Social Market in Krendang diciptakan karena adanya fenomena kepadatan yang terjadi dan menyebabkan manusia tidak lagi memiliki wadah untuk mereka beraktivitas dengan baik pada kehidupa sehari - hari mereka. Selain itu hal ini juga terjadi karena sering adanya masalah seperti kebakaran di kawasan Krendang. Maka dari itu Motherhood Community and Social Market in Krendang di harapkan dapat menghadirkan fasilitas bagi kaum ibu dan anak yang layak dan juga agar terciptanya suatu kondisi sosial yang baik pada Third Place.
\end{abstract}

Kata kunci: ibu kota; kepadatan; ruang; sosial; third place

\begin{abstract}
The city has traces of human civilization from time to time with various phenomena that occur. As time goes by, the existence of Third Place in Jakarta remains limited. The activities among those Third Places tend to be less interactive. Most of Third Places aim to address the concept of green and open space, but it fails to communicate its crucial purposes as platfrom activities for the community. In this modern era, the concept is change necessary where it accomodates public needs and no longer be depicted a mere open space. Krendang needs a facility to accommodate motherhood and children activities as the third place. As the people become more individualistic and don't want to socialize, it is more difficult to find leisure and creativity facilities. Motherhood Community and Social Market in Krendang was designed to facilitate the activities of mother and children in the middle of densely population in Krendang, Tambora, West Jakarta.
\end{abstract}

Keywords: city; density; mother; social; space; third place

\section{PENDAHULUAN}

Kecamatan Tambora sejak tahun 2011 ditetapkan sebagai kecamatan terpadat se- Asia tenggara. Hal ini dikarenakan sejak dulu wilayah Tambora merupakan pusat perdagangan dan jasa, sehingga menarik banyak pendatang dari luar kota. Kelurahan Krendang salah satu kelurahan terpadat di Kecamatan Tambora. Kelurahan ini memiliki masalah mendasar seperti keamanan dan kenyamanan, kepadatan, dan minimnya ruang terbuka untuk warga. (Sumber: BPS DKI Jakarta ) 
Manusia sebagai mahluk sosial selalu membutuhkan interaksi sosial dengan sesamanya dalam daur hidupnya. Ruang publik telah menjadi latar bagi perkembangan kehidupan publik, baik dalam kegiatan ekonomi, sosial, hiburan, hingga politik. Berlangsungnya kehidupan publik atau interaksi sosial sangat bergantung pada keberadaan dan perkembangan ruang publik. Minimnya ruang publik sebagai akibat pengembangan yang hanya berorientasi pada kepentingan kapital, mengakibatkan masyarakat mengatasinya secara mandiri. Mereka mengadakan sendiri ruang publik di lingkungan pemukimannya dengan kemungkinan akses yang lebih besar. Sebuah lapangan terbuka di tengah pemukiman misalnya, tidak jarang menjadi ajang sosialisasi para warga. Begitu juga dengan gardu ronda, sumur komunal, serta jalan-jalan di depan rumah.

Jalan-jalan di dalam perumahan Krendang hingga perkampungan difungsikan oleh warga setempat sebagai ruang untuk bersosialisasi dengan tetangga atau tempat melakukan aktivitas seperti mencuci kendaraan, bermain, berolahraga (bulu tangkis, sepak bola, jalan-jalan) atau dalam melakukan kegiatan besar warga seperti perayaan tujuh belasan, dan masih banyak lagi. Jalan-jalan di tengah pemukiman tersebut tampaknya memenuhi banyak kriteria kehidupan ruang publik. Jalan sebagai ruang publik sangat memungkinkan warga setempat untuk melakukan aktivitas serta berinteraksi dengan aktivitas lain dan lingkungan. Sementara interaksi dengan jalan sudah tentu ada dan sudah pasti mudah dan murah karena warga tidak perlu mengeluarkan banyak tenaga atau materi untuk menjangkaunya, Keamanan dan kenyamanan relatif sulit dicapai karena rasa tidak nyaman bermain pada jalanan yang difungsikan sebagai jalanan publik dimana kendaraan bermotor dapat beraktivitas secara bebas dan merupakan pengganggu yang utama karena ketika ada kendaraan lewat sehingga beberapa aktivitas harus dihentikan.

Kepadatan juga dapat menimbulkan tidak adanya ruang bebas untuk manusia dalam beraktivitas terutama kaum ibu dan juga anak - anak. Kesesakkan terjadi dan kemudian tumpah kejalan dan menyebakan masalah..tetapi pada saat yang sama juga menjadi third place untuk mereka, karena itu saya ingin menggeser kondisi itu ke sebuah tempat yang juga menjadi kehidupan keseharian mereka yaitu pasar..Hal ini pun berimbas pada minimnya pasokan gas oksigen untuk manusia yang terjadi dan menyebabkan rasa tidak menyenangkan untuk berada pada tempat tersebut. Pada pertumbuhannya penghijauan dapat menghasilkan oksigen yang sangat diperlukan untuk pernapasan makhluk hidup. Manfaat lainnya adalah sebagai pengatur lingkungan, karena vegetasinya akan menimbulkan hawa lingkungan setempat yang sejuk dan nyaman maka diciptakanlah Vertical Farming didalamnya. Selain itu juga kepadatan pada kawasan Krendang menyebabkan masalah kebakaran yang sering terjadi pada kawasan ini, maka munculah dapur untuk umum dimana dapur ini diharapkan dapan menekan angka bahaya kebakaran. proyek ini diharapkan dapat membantu permasalahan kepadatan yang terjadi dan dapat menjadi ruang ketiga yang nyaman dan aman bagi masyarakat Krendang.

\section{KAJIAN LITERATUR}

Open Architecture, merupakan The Third Place bagi masyarakat kota, yang berfungsi sebagai ruang antara, ruang yang bukan tempat tinggal, dan juga bukan merupakan tempat kerja. The Third Place adalah sebuah program yang akan membantu masyarakat kota agar bersifat humanis, terbuka, dinamis, dan produktif. Open architecture merupakan sistem yang terbuka dan mampu beradaptasi dengan kepentingan terpilih. Konflik - konflik yang terjadi dari masyarakat kota dapat dipecahkan atau dilakukan pendekatan melalui rangkaian pendekatan desain dan juga strategi perancangan. Open Architecture sebagai dapat didefinisikan dengan melihat hal - hal penting yang terkait dengan konteks kebutuhan masyarakat kota dan modernitas yang berorientasi pada teknologi, informasi, dan individu. 


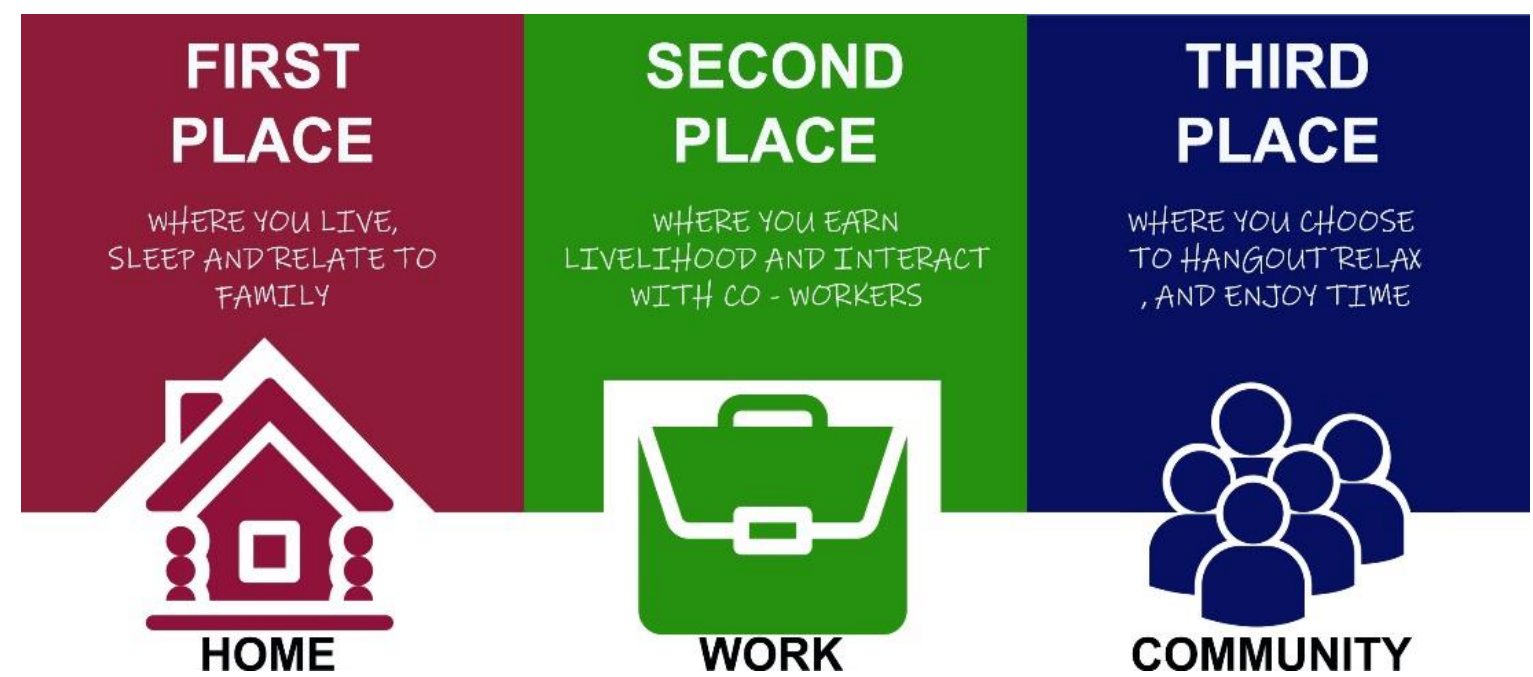

Gambar 1. The Third Place

Sumber: Penulis, 2019

Namun kebutuhan masyarakat kota dan aspek modernitasnya menimbulkan berbagai konflik seperti public - private - blur, closeness - openess - voidness, transparent - translucent opaque, exclusive - inclusive - speciality, natural - artificial - superficial, interior - exterior mobius, dan boudaries - edges - territories. Kondisi ini menciptakan kesulitan tersendiri yang harus dipecahkan secara arsitektural yaitu Open Architecture sebagai Third Place.

Pengertian third place menurut Rey Oldenburg (1999) mengatakan bahwa third place merupakan tempat untuk orang yang ingin mengobati stress, kesepian, dan keterasingan. Pengertian dari third place adalah suatu tempat yang dapat dijadikan sebagai tempat berlindung sementara dari kebosanan. Tidak hanya dijadikan sebagai tempat untuk melarikan diri, tetapi dimana orang akan bersantai dan terasa terhibur dan juga mendapatkan ketenangan di dalamnya.

Pada third place orang melarikan diri dari first place (rumah) dan second place (tempat kerja atau sekolah) untuk membuka jati dirinya dan membuka diri dengan tujuan untuk bersosialisasi di dalamnya. Rey Oldenburg (1999) mengungkapkan bahwa ada 8 karakter yang membentuk third place yaitu neutral, leveler, conversation is the main city, third places are accessible, third places have regulars, third places are physically plain and unpretentious, the dominant mood of a third place is playful, dan a home away from home.

\section{Ruang Publik}

Ruang publik adalah tempat dimana orang pergi dengan tujuan tertentu. Untuk mencari suasana yang tenang, orang pergi ke taman-taman, untuk melakukan perdagangan, orang pergi ke pasar. Kita menghabiskan waktu di tempat-tempat publik tersebut karena kebutuhan kita bukan karena suatu keharusan. Ruang publik menarik karena memberi kesempatan untuk terjadi interaksi. Sejauh ini belum ada sebuah formula atau rumusan khusus untuk menciptakan ruang publik yang berhasil.

Ruang publik didefinisikan sebagai ruang atau tempat dimana setiap orang dapat bebas keluar masuk tanpa dipungut suatu bayaran. Contohnya adalah jalan dan taman umum dimana setiap orang bebas memasuki dan menggunakannya. Karena bersifat bisa digunakan atau dimasuki setiap orang, ruang publik tidak mempertimbangkan aspek privasi bagi penggunanya. Keseimbangan kehidupan publik-privat dan dampaknya pada ruang dipengaruhi oleh berbagai faktor seperti fisik, sosial, politik dan ekonomi yang telah berevolusi sepanjang sejarah. 
Tabel 1. Kebutuhan manusia - kriteria dasar bangunan berkelanjutan pada kota

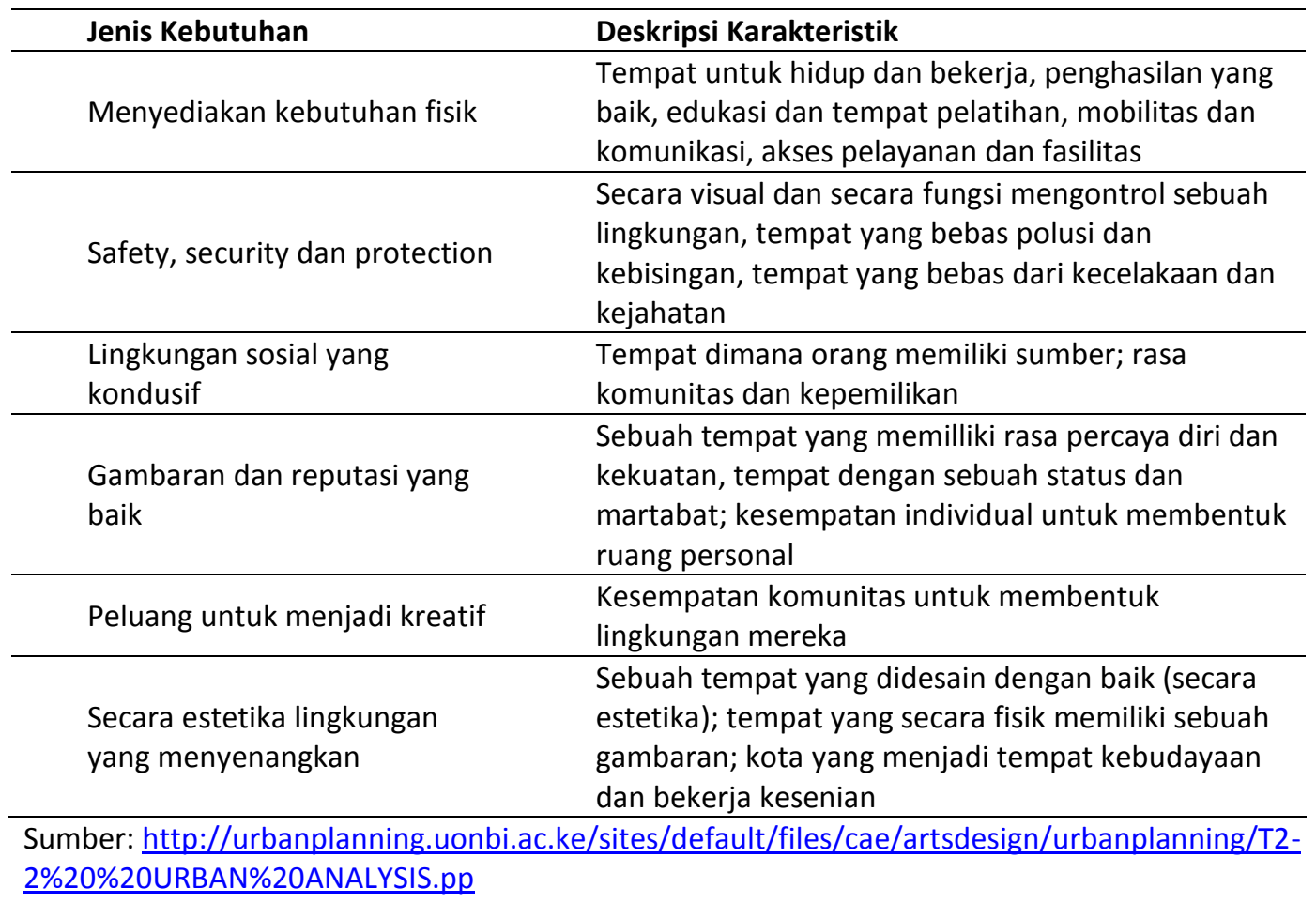

\section{Tinjauan Pasar Secara Umum}

Pasar adalah tempat dimana terjadi interaksi antara penjual dan pembeli. Pasar adalah salah satu dari berbagai sistem, intuisi, prosedur, hubungan sosial, dan infrastruktur dimana usaha menjual barang baru.

Pasar tradisional sebagian pasar yang dibangun dan dikelola oleh pemerintah. Pemerintah Daerah, Swasta, Badan Usaha Milik Negara, dan Badan Usaha Milik Daerah termasuk kerjasama dengan swasta dengan tempat usaha berupa toko, kios, los, dan tenda yang dimiliki/dikelola oleh pedagang kecil, menengah, dengan usaha skala kecil, modal kecil dan dengan proses jual beli barang dagangan melalui tawar menawar (Perda Makassar No. 15 tahun 2009).

Menurut Geertz, 1963 (dalam Galuh Oktaviana, 2011 :28), bahwa pasar tradisional menunjukkan suatu tempat yang diperuntukkan bagi kegiatan yang bersifat indigenos market trade, sebagaimana telah dipraktikkan sejak lama (mentradisi). Pasar tradisional lebih bercirikan bazar type economis skala kecil. Karenanya, pasar tradisional secara langsung melibatkan lebih banyak pedagang yang saling berkompetisi satu sama lain di tempat tersebut. Selain itu, pasar ini menarik pengunjung yang lebih beragam dari berbagai wilayah.

Ciri-ciri pasar tradisional adalah sebagai berikut:

a. Adanya sistem tawar menawar antara penjual dan pembeli. Tawar menawar mampu memberikan dampak psikologi yang penting bagi masyarakat. Setiap orang yang berperan pada transaksi jual beli akan melibatkan seluruh emosi dan perasaannya, sehingga timbul interaksi sosial dan persoalan kompleks. Penjual dan pembeli saling bersaing mengukur kedalaman hati masing-masing, lalu muncul pemenang dalam penetapan harga. Tarik tambang psikologi itu biasanya diakhiri perasaan puas pada keduanya. Hal ini yang dapat menjalin hubungan sosial yang lebih dekat. Konsumen dapat menjadi langganan tetap stan pada pasar tradisional. Kelancaran komunikasi sosial antar pembeli dan penjual dalam pasar tradisional tersebut menunjang ramainya stan tersebut. (kasdi, 1995) maka, dibutuhkan ruang sirkulasi berupa ruang pendestrian dengan lebar yang cukup. 
b. Pedagang di pasar tradisional berjumlah lebih dari satu, dan pedagang tersebut memiliki hak atas stan yang telah dimiliki, dan memiliki hak penuh atas barang dagangan pada stan masing-masing, sehingga tidak terdapat satu manajemen seperti yang ada di pasar modern.

c. Ciri pasar berdasarkan pengelompokan dan jenis barang pasar, yakni: Menurut Lilananda (dalam Galuh Oktaviana, 2011 : 34), jenis barang di pasar umumnya dibagi dalam empat kategori : 1) Kelompok bersih (kelompok jasa, kelompok warung, toko) 2) Kelompok kotor yang tidak bau (kelompok hasil bumi dan buahbuahan) 3) Kelompok kotor yang bau dan basah (kelompok sayur dan bumbu) 4) Kelompok bau, basah, kotor, dan busuk (kelompok ikan basah dan daging).

Tempat-tempat yang strategis selalu diminati oleh pedagang karena terlebih dahulu terlihat atau dikunjungi oleh pembeli. Tempat staregis yang dimaksud adalah sirkulasi utama, dekat pintu masuk, dekat tangga, atau dekat hall.

a. Kios Merupakan tipe tempat berjualan yang tertutup, tingkat keamanan lebih tinggi dibanding dengan yang lain. Dalam kios dapat ditata dengan berbagai macam alat display. Pemilikan kios, tidak hanya satu saja tetapi dapat beberapa kios sesuai dengan kebutuhan yang diinginkan.

b. Los Merupakan tipe tempat berjualan yang terbuka, tetapi telah dibatasi secara pasti (dibatasi dengan barang-barang yang sukar bergerak, misalnya lemari, meja, kursi, dan sebagainya) atau bersifat tetap.

c. Oprokan / Pelataran Merupakan tipe tempat berjualan yang terbuka atau tidak dibatasi secara tetap. Tetapi mempunyai tempatnya sendiri. Yang termaksud pedagang oprokan di pasar adalah pedagang asongan yang berjualan di dalam pasar maupun yang di luar pasar tetapi masih menempel di dinding pasar.

\section{Penghijauan Pada Bangunan}

Penghijauan bangunan harus memaksimalkan segala aspek dalam sebuah bidang bangunan, Menurut ilmuwan dari Universitas Birmingham dan Lancaster berargumentasi bahwa penghijauan jalanan dapat mengurangi $30 \%$ reduksi pada polusi udara. Ini berdasarkan riset yang di terbitkan pada jurnal Environmental Science and Technology Periset menemukan bahwa polusi tidak dapat dengan mudah dihindari dan tanaman memiliki kesempatan yang lebih baik dibanding filtrasi polusi udara. Daripada mengurangi polusi 1-2\%,.

Arsitektur berkelanjutan, adalah sebuah konsep terapan dalam bidang arsitektur untuk mendukung konsep berkelanjutan, yaitu konsep mempertahankan sumber daya alam agar bertahan lebih lama, yang dikaitkan dengan umur potensi vital sumber daya alam dan lingkungan ekologis manusia, seperti sistem iklim planet, sistem pertanian, industri, kehutanan, dan tentu saja arsitektur. Kerusakan alam akibat eksploitasi sumber daya alam telah mencapai taraf pengrusakan secara global, sehingga lambat tetapi pasti, bumi akan semakin kehilangan potensinya untuk mendukung kehidupan manusia.

Fungsi hijau dalam ruang terbuka hijau (RTH) kota sebagai 'paru-paru' kota, merupakan salah satu aspek berlangsungnya fungsi daur ulang, antara gas karbondioksida (CO2) dan oksigen (O2). Tumbuhan hijau juga berperan penting di lingkungan sekitar kita. Tanpa tumbuhan hijau, lingkungan di sekitar kita akan terasa panas dan tidak nyaman. Apalagi jika tumbuhan menghilang dalam skala yang cukup besar setiap tahun akibat penebangan liar dan sebagainya, tentu akan berdampak negatif terhadap keadaan atmosfer bumi. Tumbuh-tumbuhan hijau menerima sinar matahari, air $\left(\mathrm{H}_{2} \mathrm{O}\right)$ dan karbon dioksida $\left(\mathrm{CO}_{2}\right)$ dari lingkungan sekitarnya yang kemudian akan diubah menjadi oksigen $\left(\mathrm{O}_{2}\right)$ dan karbohidrat $\left(\mathrm{C}_{6} \mathrm{H}_{12} \mathrm{O}_{6}\right)$. Senyawa-senyawa yang dihasilkan oleh tumbuhan hijau melalui proses fotosintesis tersebut dibutuhkan oleh manusia dan hewan untuk melangsungkan kehidupannya.

\section{Oksigen $\left(\mathrm{O}_{2}\right)$}

Oksigen (O2) adalah salah satu komponen gas dan unsur vital dalam proses metabolisme. Oksigen memegang peranan penting dalam semua proses tubuh secara fungsional serta 
kebutuhan oksigen merupakan kebutuhan yang paling utama dan sangat vital bagi tubuh. Oksigen diperlukan sel untuk mengubah glukosa menjadi energi yang dibutuhkan untuk melakukan berbagai aktivitas, seperti aktivitas fisik, penyerapan makanan, membangun kekebalan tubuh, pemulihan kondisi tubuh, juga penghancuran beberapa racun sisa metabolisme.

Oksigen merupakan salah satu kebutuhan yang diperlukan dalam proses kehidupan karena oksigen sangat berperan dalam proses metabolisme tubuh. Kebutuhan oksigen didalam tubuh harus terpenuhi karena apabila berkurang maka akan terjadi kerusakan pada jaringan otak dan apabila berlangsung lama akan menyebabkan kematian. Proses pemenuhan kebutuhan oksigen pada manusia dapat dilakukan dengan cara pemberian oksigen melalui saluran pernafasan, pembebasan jalan nafas dari sumbatan yang menghalangi masuknya oksigen, memulihkan dan memperbaiki organ pernafasan agar berfungsi secara normal. Seperti kita ketahui, darah membawa oksigen. Aliran darah yang lancar akan memberikan otak nutrisi dan oksigen yang cukup.

Oksigen juga bisa menghasilkan hormon yang bisa membuat kita merasa lebih baik dan bahagia. Memiliki perasaan yang positif tentunya juga memberikan manfaat yang menyehatkan bagi otak kita.

a. Endorfin Hormon ini merupakan obat penghilang rasa sakit alami tubuh anda yang mampu memblokir rasa sakit.

b. Serotonin Ini adalah kunci hormon kebahagiaan. Serotonin mengatur suasana hati, mencegah depresi pada diri Anda.Cara untuk meningkatkan kadar serotonin berada di bawah sinar matahari sinar matahari menyebabkan tubuh anda untuk memproduksi vitamin $D$, yang memicu pelepasan serotonin.

c. Dopamin Dopamin adalah hormon kesenangan yang dilepaskan ketika anda berusaha menuju tujuan. Hormon ini memotivasi anda untuk bekerja keras mencapai tujuan tersebut. Inilah hormon yang membuat anda waspada dan fokus akan suatu hal.

d. Oksitosin Oksitosin adalah hormon cinta yang dilepaskan terkait hubungan percintaan dan melahirkan. Hormon ini juga meningkatkan perasaan cinta dan kepercayaan terhadap seseorang.

\section{METODE}

Dalam menciptakan sebuah karya arsitektur perlu adanya sebuah tapak yang mendukung sebuah program yang diusulkan. Program yang diusulkan adalah program yang bersifat sosial, hiburan dan keramahtamahan. Didalamnya terdapat sebuah konteks yang general dan memiliki sebuah target pengunjung yaitu kaum ibu rumah tangga yang tidak dapat meninggalkan kesehariannya dan juga anak - anak. Oleh sebab itu pemilihan lokasi yang tepat adalah di sebuah perkampungan yang terletak di perkotaan padat yang memiliki sebuah kehidupan yang sangat padat dan produktifitas yang sangat tinggi. Selain itu desain sangat dipengaruhi oleh konteks perkotaan dimana kepadatan penduduk menjadikan sebuah bangunan harus beradaptasi dengan lahan yang semakin minim. Oleh sebab itu perancang memberi sebuah ruang yang lebih bebas untuk penghijauan kota dan memilih untuk membangun bangunan ikonik untuk terciptanya keharmonisan didalam perkotaan dan juga untuk memberi "Bilbao effect" dimana nantinya efek ini akan memberi efek lebih baik terhadap tempat atau kawasan tersebut.

Bentuk bangunan dalam suatu tempat biasanya hadir secara terus-menerus dalam rentang waktu yang sangat lama, dan tidak jarang hadir pula diberbagai daerah dan bahkan sangat berjauhan. Peniruan yang berulang-ulang pada akhirnya akan mengakibatkan terbentuknya image dalam masyarakat yang bersangkutan bahwa bentukan tersebut adalah bentukan yang ideal bagi mereka yang perlu dipertahankan, sehingga terbentuklah tipologitipologi bangunan. Dari latar belakang tersebut dapat didefinisikan bahwa pendekatan ikonik dalam mendesain adalah mendesain dengan cara mengacu ( meniru) bentukan yang telah ada sebelumnya yang dianggap ideal dan perlu di pertahankan. Pendekatan ikonik biasanya akan lebih memiliki keterkaitan dengan masyarakat, karena masyarakat sudah "kenal" dan merasa 
"dekat" dengan tampilan dari bangunan tersebut. Sedangkan arsitektur ikonik biasanya akan menjadi penanda atau ciri khas dari suatu tempat atau daerah karena tampilannya. Namun sering kali bangunan ikonik malah kehilangan relasi dengan lingkungan sekitarnya atau masyarakat yang menggunakannya, jadi bangunan tersebut hanya "bagus" dilihat sendiri (terkesan egois).

\section{Data Kawasan}

Posisi wilayah Krendang berada di tengah-tengah pusat perniagaan bertaraf Nasional dan Internasional sehingga menarik pengusaha untuk menjadikan Wilayah Kelurahan Krendang sebagai lokasi berproduksi dan berusaha di bidang sandang (usaha konveksi) mengingat letak Pasar Pagi, Mangga Dua, Pasar Tanah Abang sangat dekat dengan wilayah Krendang, dan juga terdapat banyak usaha kuliner yang menjual berbgai macam kuliner khas Kalimantan Barat ( Pontianak, Singkawang ) Sedangkan peruntukan tanah terdiri dari pemukiman baik pribadi maupun kontrakan : $65 \%$, perniagaan / usaha : $35 \%$, pekarangan dan pertanian : $0 \%$.

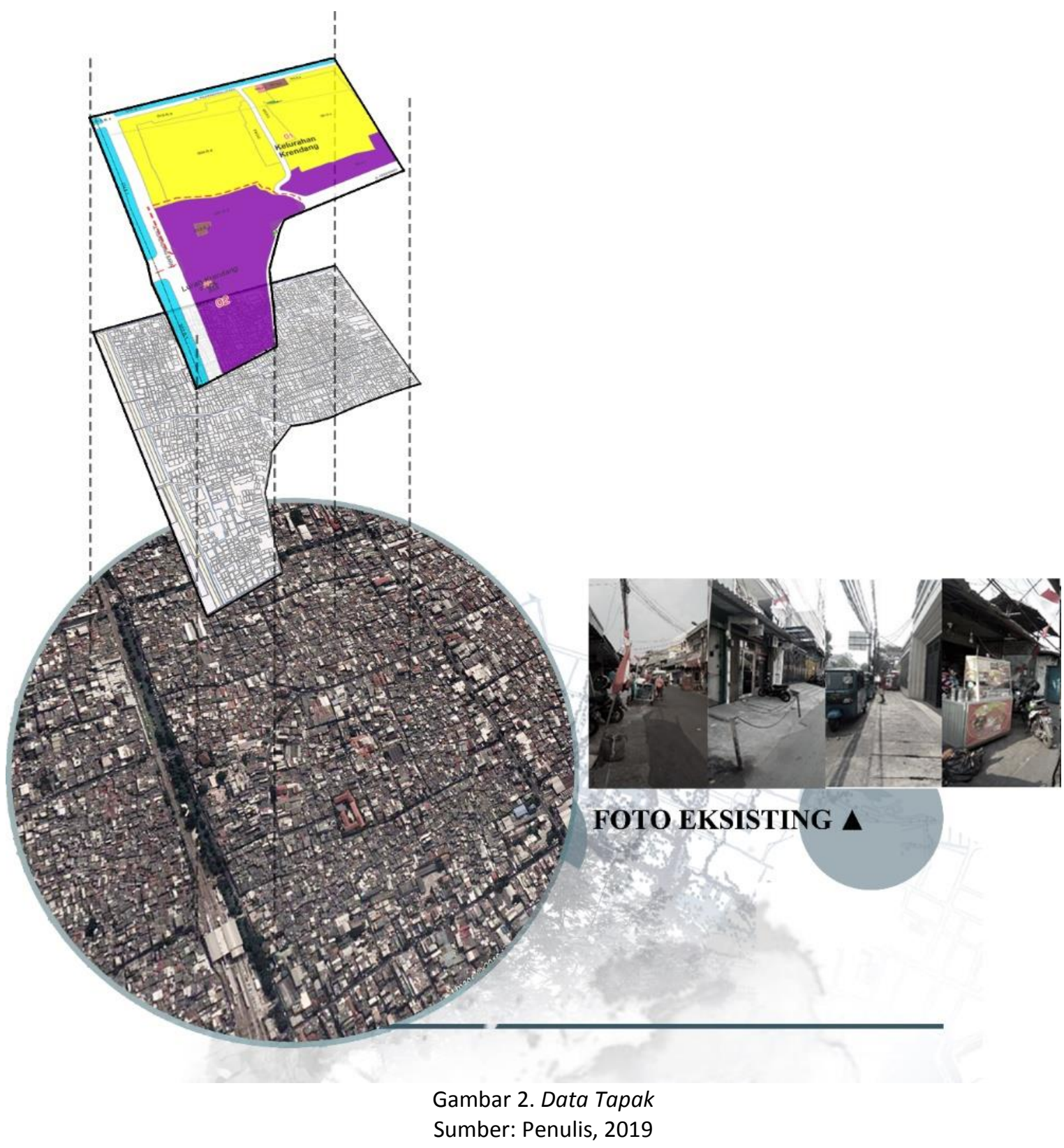




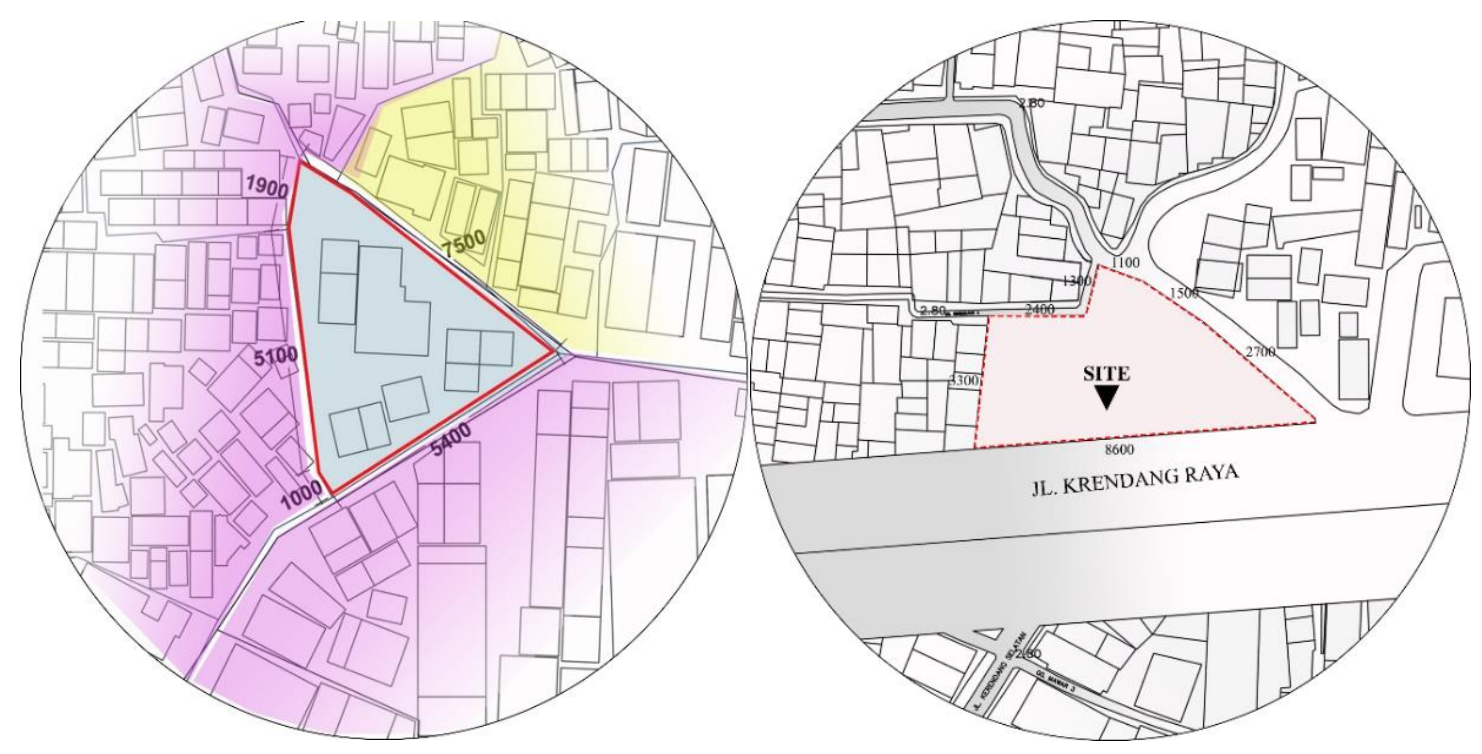

Gambar 3. Data Tapak

Sumber: Penulis, 2019

Tapak terdapat kelurahan kerendang, jl. krendang raya tambora, jakarta barat dimana luas lahan sebesar $2.386 \mathrm{~m} 2$, Pemilihan tapak berdasarkan kesesuaian akan program ruang yang berdekatan dengan lingkungan yang memiliki produktifitas yang tinggi pada kawasan tapak, dan lingkungan perumahan serta wadah komunitas untuk kaum ibu dan juga anak - anak namun tidak menutup akses bagi masyarakat luas untuk bermain dan berkunjung ke dalam bangunan.

\section{DISKUSI DAN HASIL}

Berdasarkan kebutuhan akan sebuah kebutuhan dapat disimpulkan bahwa kawasan Krendang memiliki permasalahan seperti kepadatan yang menyebabkan stressor lingkungan hingga minimnya penghijauan yang menyebabkan pasokan gas oksigen berkurang.

Pemilihan tapak berdasarkan dengan analisa yang dituju dimana ingin Menyediakan wadah ruang ketiga untuk masyarakat. Kesesuaian akan program ruang yang berdekatan dengan lingkungan yang memiliki produktivitas tinggi, lingkungan perumahan serta wadah komunitas tiong hoa Kalimantan Barat yang kental didalamnya. Memilih kawasan pada pusat kota merupakan tujuan utama karena tingkat kebutuhan ruang ketiga yang tinggi, tapak yang dipilih berada pada Kecamatan Tambora, Kelurahan Krendang, Tambora menjadi salah satu kawasan terpadat se - Asia Tenggara yang belum mendapatkan penanganan secara tepat oleh pemerintah. Kawasan ini merupakan kawasan yang padat akan penduduk dengan sedikit ruang terbuka hijau.. Sejauh ini pada kawasan Kecamatan Tambora hanya memiliki satu RPTRA yakni berada pada RPTRA Krendang. Kawasan ini di rasa tepat untuk diciptakannya ruang ketiga karena pada masa yang akan datang dibutuhkan bangunan yang berkelanjutan untuk sebuah kota dan memperbaiki kualitas hidup masyarakat. Didalamnya ramah terhadap lingkungan, dan dapat memberi kualitas hidup yang lagi baik dari segi lingkungan maupun kegiatannya. Dan menjadi sebuah ruang publik yang berlangsung selama 24 jam. 

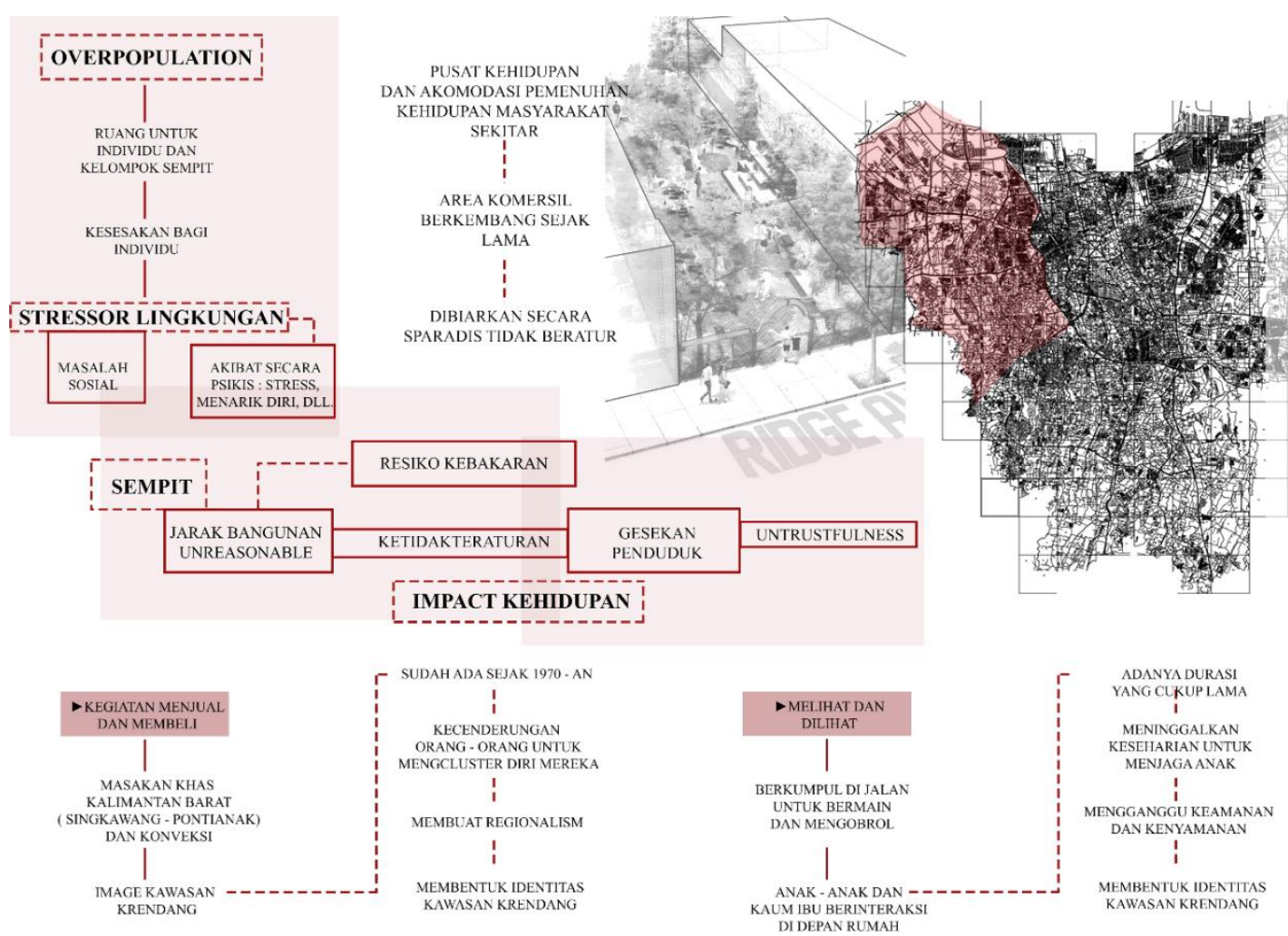

Gambar 4. mapping masalah tapak Sumber: Penulis, 2019

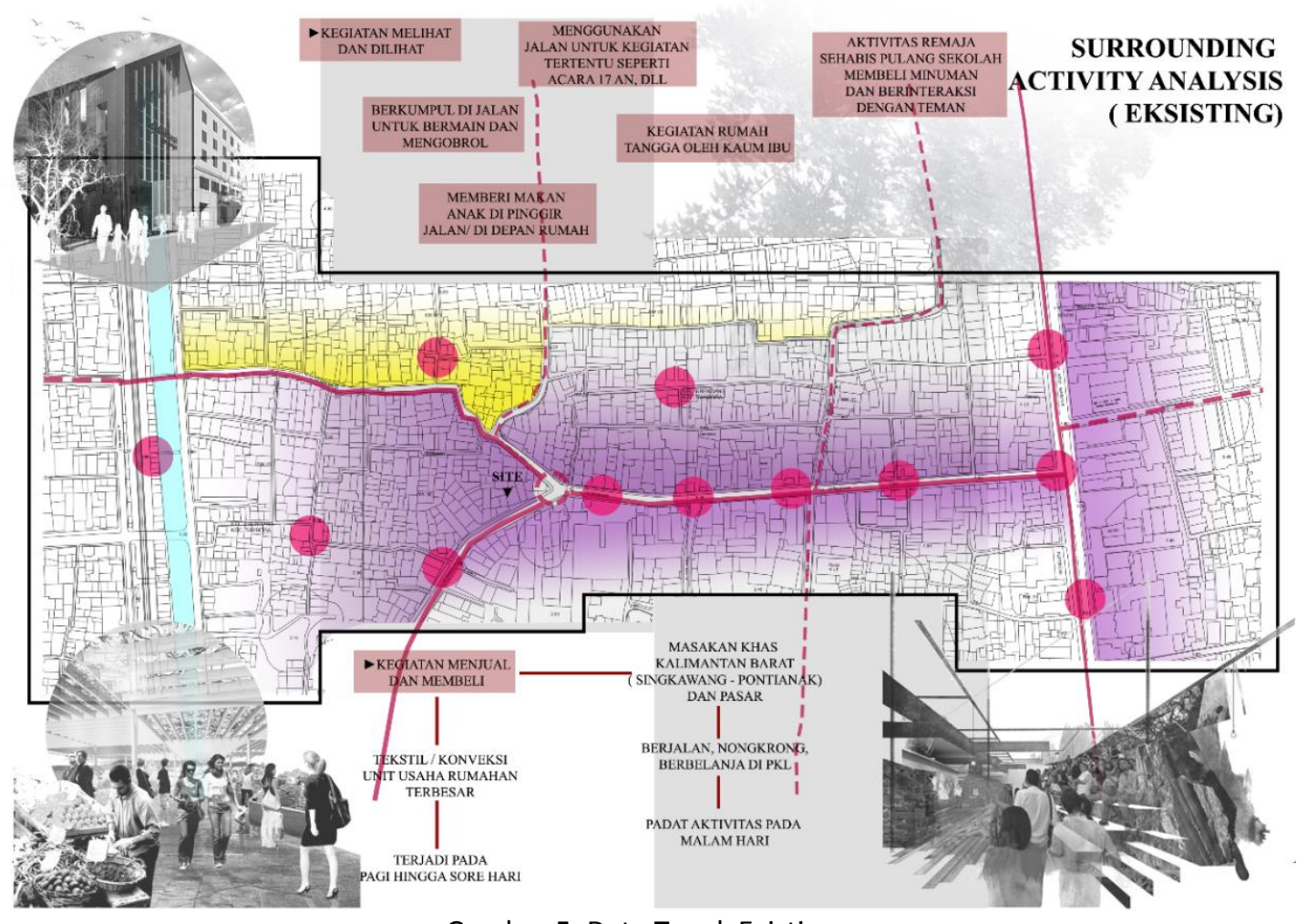

Gambar 5. Data Tapak Existing Sumber: Penulis, 2019 


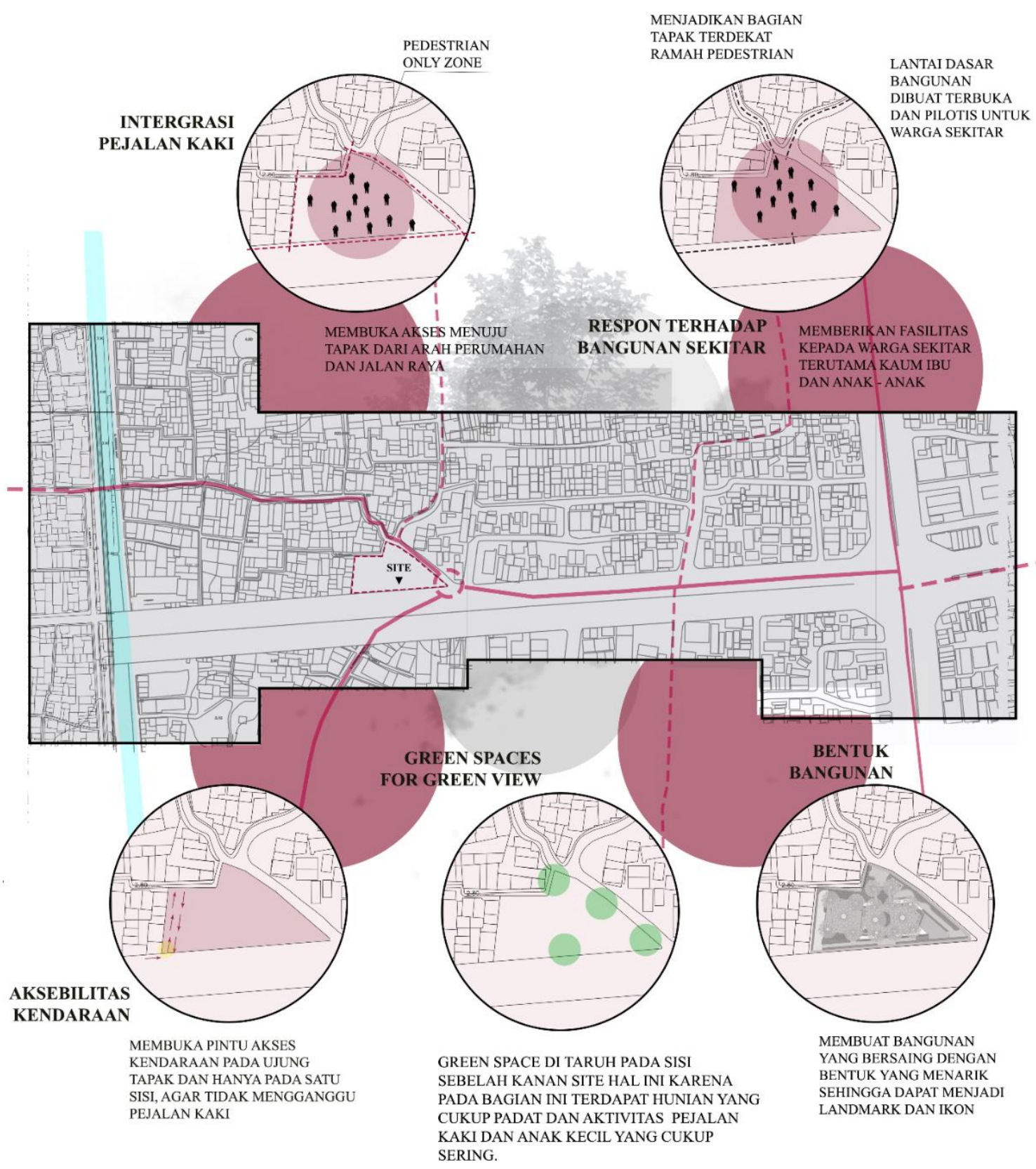

Gambar 6. Data Tapak

Sumber: Penulis, 2019 


\section{KONSEP : MOTHERHOOD COMMUNITY AND SOCIAL MARKET}
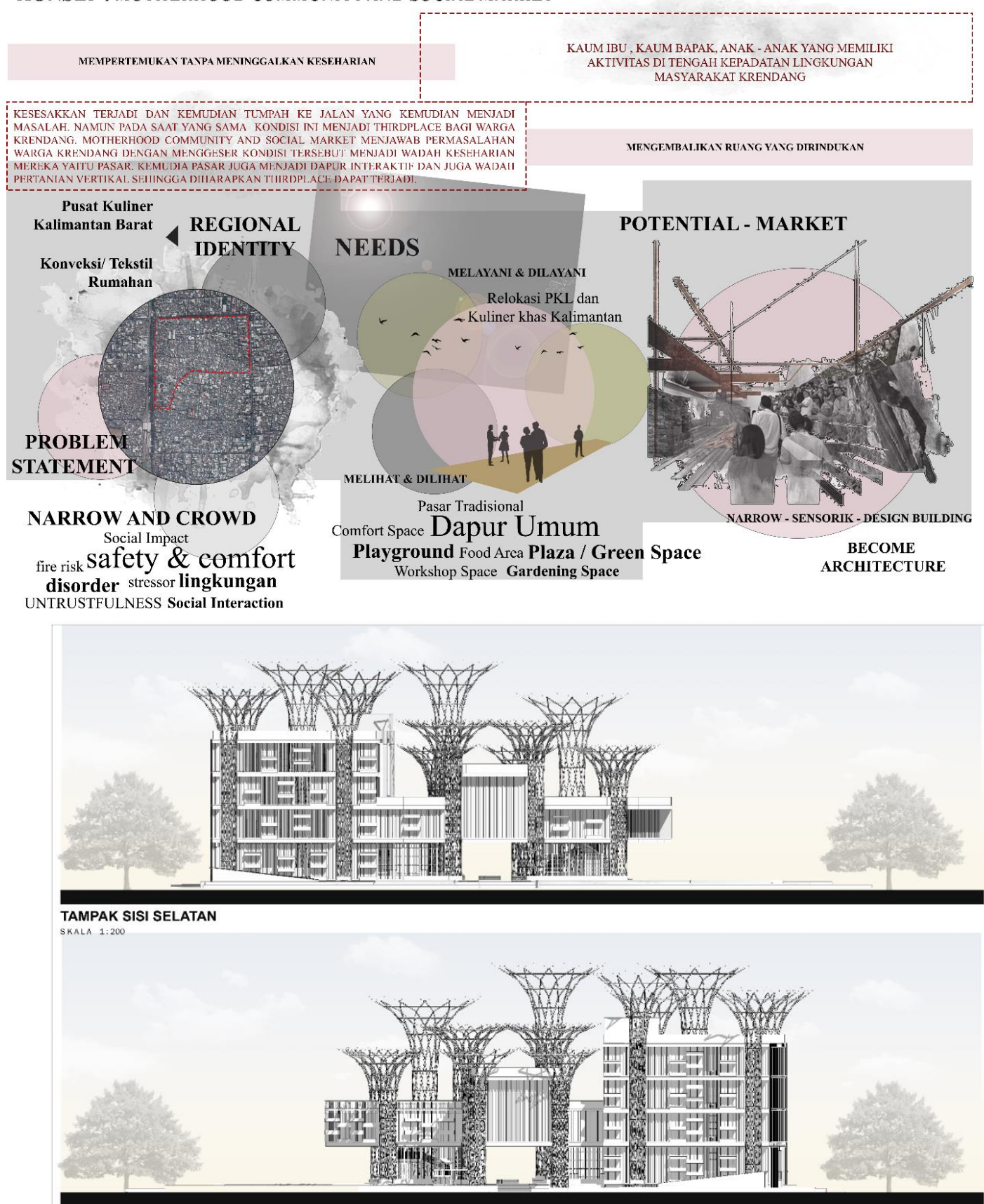

TAMPAK SISI UTARA

SKALA $1: 200$

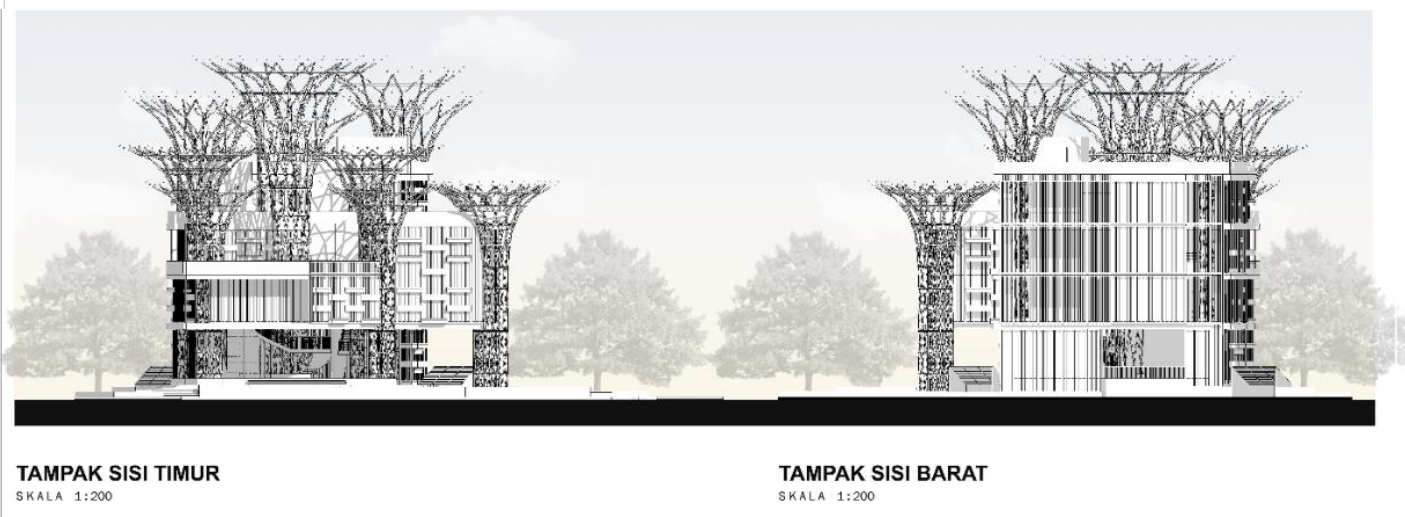

Gambar 7. Konsep

Sumber: Penulis, 2019 
Memiliki konsep motherhood dimana motherhood disini diartikan sebagai sesuatu yang merangkul dan memeluk kedalam, maka di buatlah kolom struktur yang memiliki bentuk melengkung seperti merangkul. Kolom tersebut berfungsi sebagai water catcher dan juga sun catcher yang berguna untuk menyiram dan juga menyinari tanaman vertikal yang berada pada bangunan.

Bentuk bangunan dalam suatu tempat biasanya hadir secara terus-menerus. peniruan yang berulang-ulang pada akhirnya akan mengakibatkan terbentuknya image dalam masyarakat. bentukan tersebut adalah bentukan yang ideal bagi mereka yang perlu dipertahankan, sehingga terbentuklah tipologi bangunan yang baru bagi kawasan Krendang.

\section{KESIMPULAN DAN SARAN}

Ruang publik dan segenap fasilitasnya merupakan salah satu indikator kualitas hidup di perkotaan. Keberadaannya diharapkan dapat meningkatkan kualitas hidup penduduknya. Akan tetapi fakta yang diperoleh dari pengembangan ruang publik di perkotaan, seringkali ditemukan bahwa keberadaannya justru diabaikan, digunakan tidak sesuai peruntukan, bahkan mendapatkan dampak dari aktivitas vandalisme oleh warga di sekitarnya.

Pelibatan masyarakat dalam proses desain ruang publik diyakini akan mengurangi kesenjangan antara idealisasi desain dengan hasilnya. Walaupun metode pelibatan pengguna ini memerlukan waktu dan tahapan yang lebih panjang, akan tetapi hasil yang nantinya akn di dapat sangatlah sebanding.

Sebuah Pasar dan Ruang Komunitas adalah wadah yang sangat memiliki nilai yang tinggi. Ruang komunitas baik terencana maupun tidak terencana masing-masing memiliki peran sosial. Peran sosial Ruang Komunitas di Perumahan Terencana sebagian besar diakomodasi dari aktivitas warga sehari - hari. Adanya aktivitas warga di Ruang Komunal Terencana memicu adanya interaksi sosial sehingga peran sosial dari Ruang Komunitas dapat dilihat dan dinilai. Dengan adanya Ruang Komunitas Ibu dan Pasar di Krendang yang beradaptasi dengan konteks perkotaan dan kebutuhan perilaku manusia akan memberikan dampak yang besar untuk kemajuan kawasan Krendang.

\section{REFERENSI}

Elisee Reclus, The Evolution of Cities, Contemporary Review, 1895 vol.67 dikutip dari lain Boyd White, Modernism and the Spirit of the City, h.246-64

Spirn, Anne Whiston "Air quality at the Street Level: Strategies for Urban Design."

Cambridge: Harvard Graduate School of Design (1986) diunduh 15 November 2019

http://digilib.mercubuana.ac.id/manager/t!@file artikel abstrak/Isi Artikel 993428294000.p df diunduh 3 januari 2020

http://repository.unika.ac.id/19507/6/14.A1.0159\%20FEBRINA\%20MELINDA\%20PUTRI\%20\%2 85.91\%29..pdf\%20BAB\%20V.pdf diunduh 3 januari 2020

http://repository.unika.ac.id/19507/6/14.A1.0159\%20FEBRINA\%20MELINDA\%20PUTRI\%20\%2

85.91\%29..pdf\%20BAB\%20V.pdf diunduh 3 januari 2020

https://iplbi.or.id/merancang-pasar-tradisional-pengalaman-di-program-studi-arsitektur-itb/ diunduh 8 september 2019

http://urbanplanning.uonbi.ac.ke/sites/default/files/cae/artsdesign/urbanplanning/T2-2\%20\%20URBAN\%20ANALYSIS.pp diunduh 20 September 2019 